WOLFGANG MAENNIG / MALTE STEENBECK / MARKUS WILHELM RHYTHMS AND CYCLES IN HAPPINESS

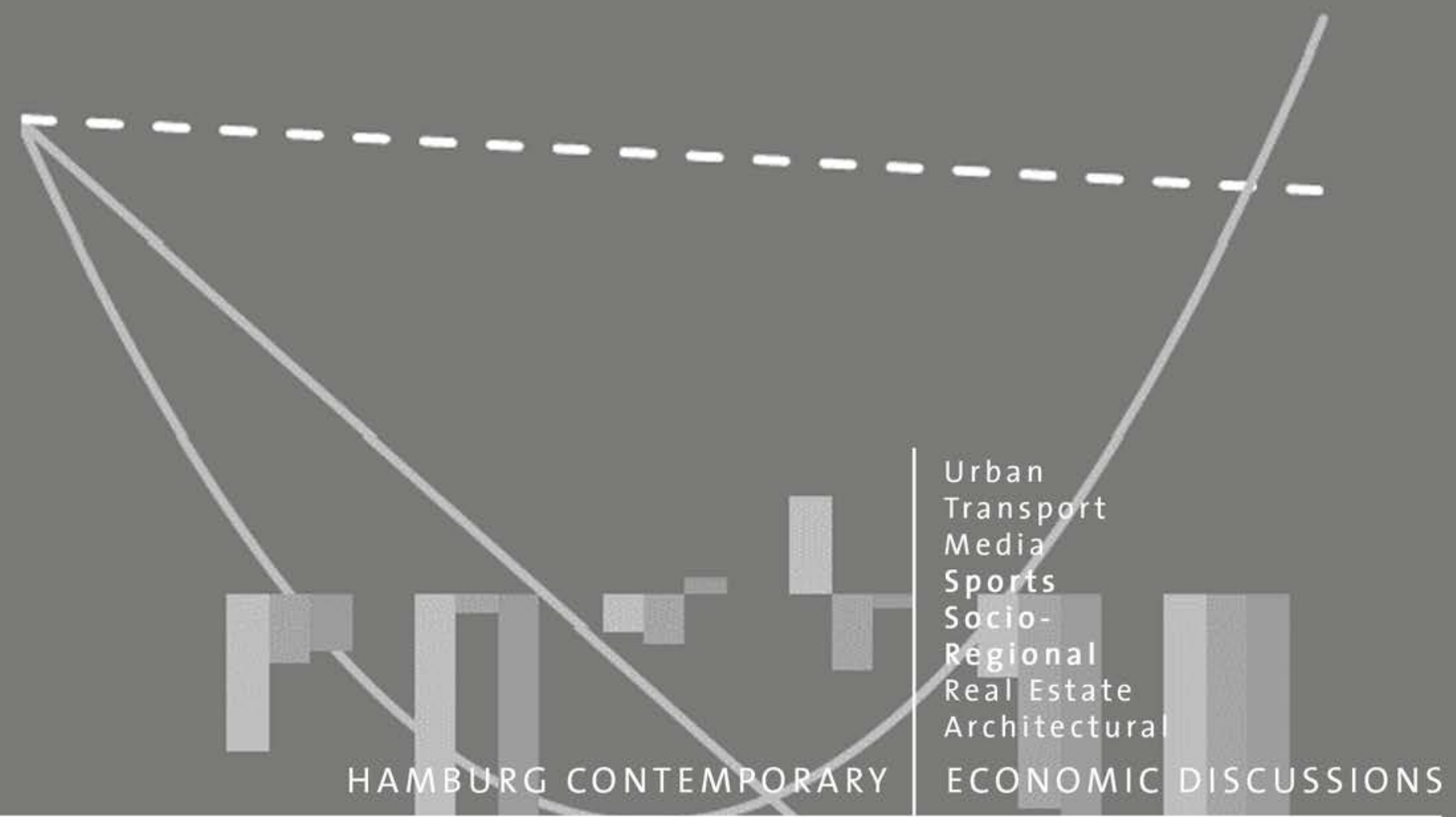

NO. 46 
Hamburg Contemporary Economic Discussions

University of Hamburg

Faculty Economics and Social Science

Chair for Economic Policy

Von-Melle-Park 5

D-20146 Hamburg | Germany

Tel $+494042838-4622$

Fax +494042838 - 6251

http://www.uni-hamburg.de/economicpolicy/

Editor: Wolfgang Maennig

Wolfgang Maennig

University of Hamburg

Faculty Economics and Social Science

Chair for Economic Policy

Von-Melle-Park 5

D-20146 Hamburg | Germany

Tel $+494042838-4622$

Fax +494042838 - 6251

wolfgang.maennig@wiso.uni-hamburg.de

Malte Steenbeck

University of Hamburg

Faculty Economics and Social Science

Chair for Economic Policy

Von-Melle-Park 5

D-20146 Hamburg | Germany

Tel +49 4042838 - 5297

Fax +494042838 - 6251

malte.steenbeck@wiso.uni-hamburg.de

Markus Wilhelm

University of Hamburg

Faculty Economics and Social Science

Chair for Economic Policy

Von-Melle-Park 5

D-20146 Hamburg | Germany

Tel +4940 42838 - 5569

Fax +494042838 - 6251

markus.wilhelm@wiso.uni-hamburg.de

ISSN 1865 - 2441 (Print)

ISSN 1865 - 7133 (Online)

ISBN 978-3-942820-06-6 (Print)

ISBN 978-3-942820-07-3 (Online) 


\title{
Rhythms and Cycles in Happiness
}

\begin{abstract}
This study analyses time-dependent rhythms in happiness in three aspects. We show that the Sunday neurosis exists exclusively for men with a medium level of education and both men and women with high levels of education. Men with high levels of education may even experience a weekend neurosis. This study is the first to test for intra-monthly rhythms and to demonstrate that men with a lower educational background may suffer from negative effects on happiness towards the end of the month, potentially due to liquidity problems. The study is also the first to demonstrate that even when controlling for health and income effects - happiness exhibits seasonal effects over the annual period, depending on gender and education.

Keywords: Happiness; life satisfaction; weekend neurosis; rhythms in time

JEL classification: D12; 121; 131; J16

Version: June 2013
\end{abstract}

\section{Introduction}

In search of non-monetary welfare measures, the focus of social and economic research has recently shifted to the analysis of happiness. In contrast to the affective components of subjective well-being, reference is made in this context to 'cognitive judgments of life satisfaction' (Lucas et al., 1996, p. 616) ${ }^{1}$. Aside from socio-economic characteristics, such as age (Frijters and Beatton, 2012), marital status and health, particularly economic aspects proved significant, such as labor market status (Winkelmann and Winkelmann, 1998; Clark and Oswald, 1994) and income (Easterlin, 1995). Potential time-specific factors, however, are aspects that have been largely ignored by economic studies. As exceptions, based on studies using data from the British Household Panel Survey (BHPS) and the German Socio-Economic Panel Study (SOEP), Taylor (2006) and Akay and Martinsson (2009) found that the day of the week can influence happiness. In Britain, the existence of Monday blues has been recognized, while the SOEP data shows a significantly negative effect on weekends, particularly on Sundays, in anticipation of the upcoming stresses of the working week.

${ }^{1}$ According to Diener et al. (1999), subjective well-being can be divided into the separately measurable components of life satisfaction/happiness, positive and negative affect, as well as the domain satisfactions. 
Outside of economic research, especially in psychological literature, there have been some, partly experimental, studies on time-specific weekday influences on happiness and mood as a rather affective component (Clark and Watson, 1988; Croft and Walker, 2001; Csikszentmihalyi and Hunter, 2003; Mihalcea and Liu, 2006; Areni and Burger, 2006). Other psychological studies have also discussed potential seasonal factors. Concerning seasonal influences Smith (1979) does not find much evidence, but Murray (2001) identifies some indicators of seasonal influences on mood, with highs in summer and lows in winter.

This study adds to the findings thus far on potential rhythms in happiness in three ways: first, using pooled panel data, in addition to studying the previously examined effects of weekdays and seasons, potential monthly rhythms are tested, too. Such monthly rhythms can emerge, for example, from liquidity problems at the end of the month. Second, as liquidity problems affect people with different levels of education differently, we control for individual educational background. Third, to the previous analyses we add the question as to whether the rhythms in happiness expressed are gender-specific ${ }^{2}$.

\section{Data and Empirical Strategy}

We use the data for the period 1994-2010 from the 2010 Long Beta version of the SOEP. We limit our analysis to the months between January and September, because only $2.0 \%$ of the SOEP surveys were conducted in the last quarter of any year. Our random sample for the following analysis comprises a total of 250734 observations and 34451 respondents. To avoid any distortions resulting from the differently sized sub-samples of the SOEP, all values are included taking into account their individual cross-section weighting, and we control for interindividual correlation.

The endogenous variable of subjective life satisfaction is analysed according to its source coding in the SOEP as an expression along an eleven-point scale ranging

\footnotetext{
${ }^{2}$ A differentiation according to the level of education seems appropriate particularly in connection with the relatively high stability over time of the issues analysed here. The inclusion of gender, thus, results in stable subgroups.
} 
from 0 ('completely dissatisfied') to 10 ('completely satisfied') ${ }^{3}$. To study the timedependent happiness rhythms, the weekdays of the respective surveys are considered by way of dummy variables, while the respective day of the month is included in the analysis on a scale of 1 to 31 . In addition, the respective day of the year of the survey is taken into account as an expression on a scale of 1 to 274 so as to map any potential seasonal factors in the course of a year ${ }^{4}$.

In order to ensure maximum variation in view of weekday, monthly and annual influences, a pooled approach is employed in the subsequent analyses. The division into subgroups differentiated by the education attained, as applied to the analyses, is based on the ISCED categories contained in the SOEP. As such, the levels of education are condensed to low (ISCED 1 and 2), medium (ISCED 3 and 4) and high (ISCED 5 and 6) (Muffels and Headey, 2011; Boertien et al., 2012).

We use the usual control variables, such as centered household income, age (linear and quadratic), health, marital status, presence of children in the household, year of the survey, and control for regional aspects (Stutzer and Frey, 2010).

Starting with the descriptive analysis, Fig. 1(a)-(f) show average life satisfaction values over time in terms of gender and level of education. Fig. 1(a) and (b) indicate a lower life satisfaction on weekends among both men and women with a medium and higher level of education. The figures do not show any such Sunday neurosis for people with a low level of education.

Fig. 1(c) and (d), which represent 7-day moving averages of happiness, show that there is only little variability among those with medium and high levels of education in the course of a month. For people with a low level of education, happiness is more variable during a month; Fig. 1(c) suggests a non-linear trend for men.

\footnotetext{
${ }^{3}$ The text of the subsequent underlying variables of the SOEP used here is: 'How satisfied are you with your life, all things considered?' (SOEP, 2010).

${ }^{4} \mathrm{~N}=274$ is the number of days from January to September in the case of a leap year.
} 
Fig. 1(e) and (f) plot 30-day moving averages of happiness for the first 274 days of the year. Men with a medium and higher level of education see a growing trend in happiness over the course of a year. For women, the average happiness increases during the year across all levels of education.

Fig. 1a Life satisfaction by weekday and level of education: Men $1994-2010$

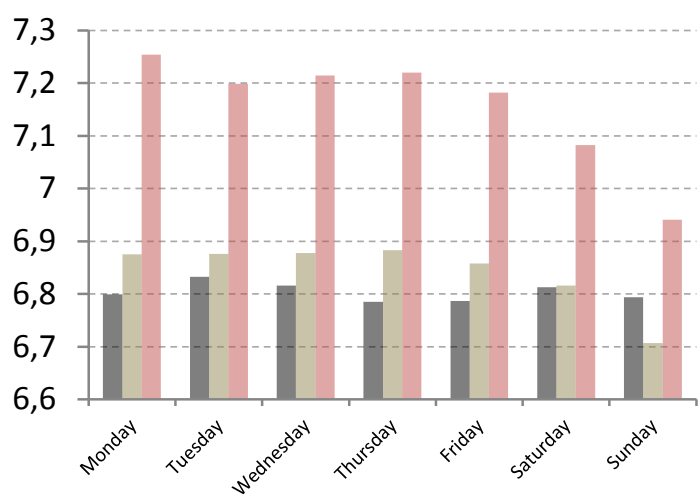

Fig. 1c Life Satisfaction by day of the month and level of education: Men $1994-2010$

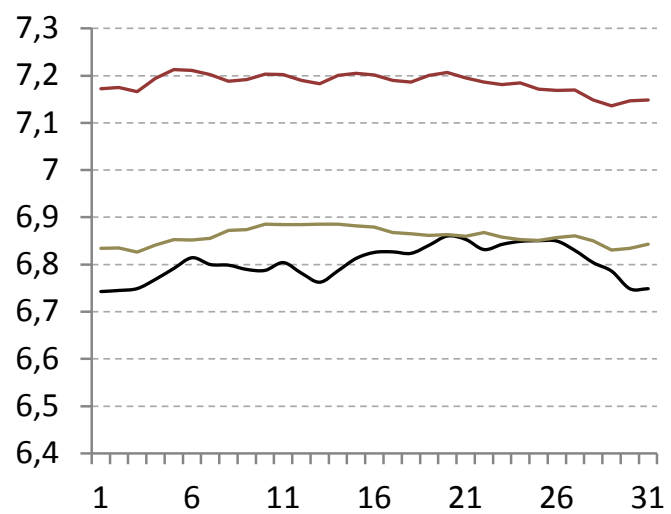

Fig.1e Life Satisfaction by day of the year and level of education: Men $1994-2010$

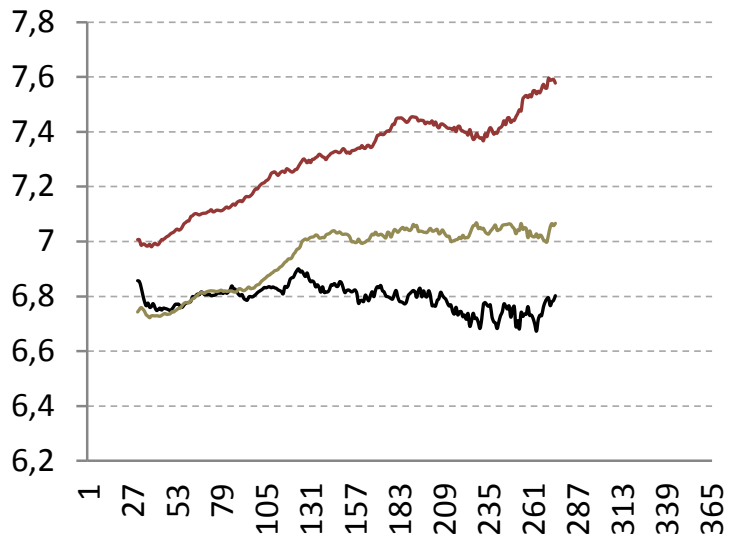

Fig. 1b Life satisfaction by weekday and level of education: Women 1994-2010

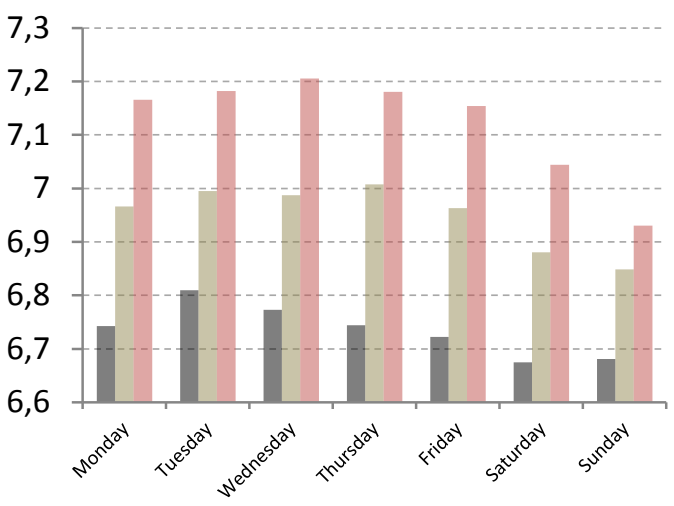

Fig. 1d Life Satisfaction by day of the month and level of education: Women $1994-2010$

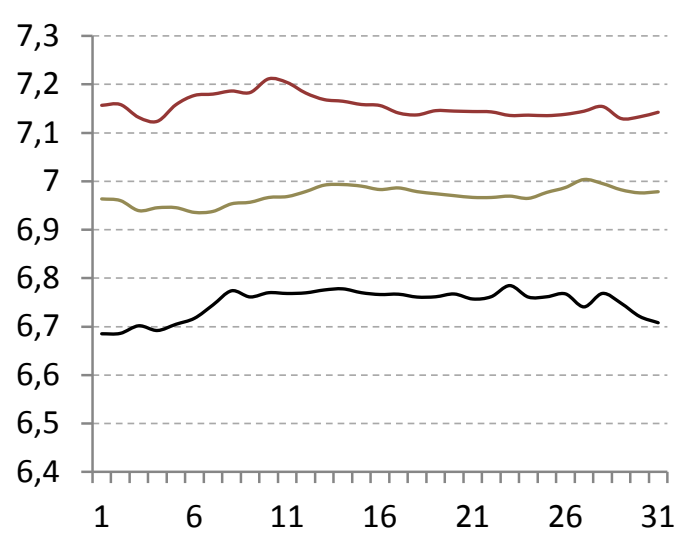

Fig. If Life Satisfaction by day of the year and level of education: Women $1994-2010$

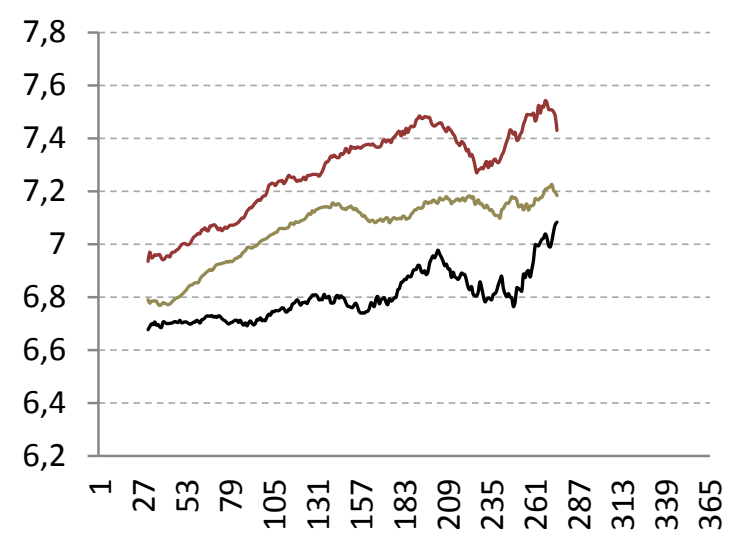

$$
\rightarrow-\text { ISCED 1, } 2
$$

Source: Own analysis, calculation and illustration, SOEP LONG Beta-Version, 2010.

Notes: Life satisfaction by gender and educational level: weighted mean (month: 7 days average; year: 30 days average). 
To account for any non-linear relationships, quadratic terms were included in the analysis for the days of the month and year. Where linear and quadratic correlations are not significant, models of multivariate analysis (Tables 1 and 2) show linear effects throughout.

Similarly to most studies on happiness, the first step involves performing OLS estimates (Ferrer-i-Carbonell and Frijters, 2004). In addition, as a further robustness check, all models are estimated using the ordered logit method - not least to also account for the ordinal character of the dependent variable (Maennig and Wilhelm, 2012).

\section{Results}

Table 1 summarizes the results of the pooled estimates for men, Table 2 for women. For clearity, we only present those estimates where the highest polynomial is significant.

The two tables first show the OLS estimates on which the interpretation of the coefficients is based. The column following the OLS estimate shows the results of the corresponding ordered logit estimate. The top half of each table shows the respective base models with the potential influencing factors of the different rhythms that impact life satisfaction. The bottom half represents the related interaction model (Aiken and West, 1991). In the interaction model, the days of the month are interacted with the household income in order to uncover potential compensatory effects caused by income ${ }^{5}$. The division according to levels of education is the same as in the descriptive analysis.

The tables do not show coefficients for the influences of the other exogenous characteristics, such as age, marital status or labor market status. The directions and significances exhibit the influences known from extensive empirical research ${ }^{6}$. The $R^{2}$ values are between 27 and 30 percent for OLS estimates, which

\footnotetext{
${ }^{5}$ In the interaction models, only the coefficients of the variables of the interaction effect involved are reported (income ${ }^{*}$ day of the month). The remaining effects of weekdays and annual rhythms are not affected, and correspond to the original models in terms of direction and significance.

${ }^{6}$ Details are available from the authors on request.
} 
can be considered high in terms of explanatory value compared to the empirical literature. However, this should not be overinterpreted (Diener et al., 1999).

Table 1: Life Satisfaction by Day of the Week, Month and Year: Level of Education - Men (Interaction Effect between Day of the month - linear and Household Income); Cross Pool Section, 1994 - 2010, OLS and Ordered Logit Regression Results

\begin{tabular}{|c|c|c|c|c|c|c|}
\hline \multirow[b]{2}{*}{ Models: } & \multicolumn{2}{|l|}{ ISCED 1, 2} & \multicolumn{2}{|l|}{ ISCED 3, 4} & \multicolumn{2}{|l|}{ ISCED 5, 6} \\
\hline & OLS & Ordered Logit & OLS & Ordered Logit & $\overline{O L S}$ & Ordered Logit \\
\hline Day of the year (linear) & $\begin{array}{l}-0.000858^{*} \\
(0.000)\end{array}$ & $\begin{array}{l}-0.001083^{* *} \\
(0.001)\end{array}$ & $\begin{array}{l}-0.000052 \\
(0.000)\end{array}$ & $\begin{array}{l}-0.000061 \\
(0.000)\end{array}$ & $\begin{array}{l}-0.002120^{* *} \\
(0.001)\end{array}$ & $\begin{array}{l}-0.002926^{* *} \\
(0.001)\end{array}$ \\
\hline Day of the year (squared) & & & & & $\begin{array}{l}0.000008^{* *} \\
(0.000)\end{array}$ & $\begin{array}{l}0.000011^{* *} \\
(0.000)\end{array}$ \\
\hline Day of the month (linear) & $0.014544^{*}$ & $0.018410^{*}$ & -0.000336 & -0.000506 & 0.000675 & 0.001447 \\
\hline & $(0.008)$ & $(0.009)$ & $(0.001)$ & $(0.001)$ & $(0.001)$ & $(0.002)$ \\
\hline Day of the month (squared) & $\begin{array}{l}-0.000496^{*} \\
(0.000)\end{array}$ & $\begin{array}{l}-0.000568^{* *} \\
(0.000)\end{array}$ & & & & \\
\hline Household Income ${ }^{\text {a }}$ & $\begin{array}{l}0.000239^{* * *} \\
(0.000)\end{array}$ & $\begin{array}{l}0.000282^{* * *} \\
(0.000)\end{array}$ & $\begin{array}{l}0.000174^{* * *} \\
(0.000)\end{array}$ & $\begin{array}{l}0.000225^{* * *} \\
(0.000)\end{array}$ & $\begin{array}{l}0.000115^{* * *} \\
(0.000)\end{array}$ & $\begin{array}{l}0.000171^{* * *} \\
(0.000)\end{array}$ \\
\hline Tuesday & $\begin{array}{l}-0.032237 \\
(0.058)\end{array}$ & $\begin{array}{l}-0.025181 \\
(0.065)\end{array}$ & $\begin{array}{l}-0.013763 \\
(0.028)\end{array}$ & $\begin{array}{l}-0.020039 \\
(0.032)\end{array}$ & $\begin{array}{l}-0.011460 \\
(0.037)\end{array}$ & $\begin{array}{l}-0.003736 \\
(0.047)\end{array}$ \\
\hline Wednesday & $\begin{array}{l}-0.075487 \\
(0.058)\end{array}$ & $\begin{array}{l}-0.064407 \\
(0.066)\end{array}$ & $\begin{array}{l}-0.003943 \\
(0.029)\end{array}$ & $\begin{array}{l}-0.016441 \\
(0.034)\end{array}$ & $\begin{array}{l}-0.049336 \\
(0.038)\end{array}$ & $\begin{array}{l}-0.042647 \\
(0.046)\end{array}$ \\
\hline Thursday & $\begin{array}{l}-0.007251 \\
(0.057)\end{array}$ & $\begin{array}{l}-0.013000 \\
(0.063)\end{array}$ & $\begin{array}{l}-0.009515 \\
(0.030)\end{array}$ & $\begin{array}{l}-0.014923 \\
(0.035)\end{array}$ & $\begin{array}{l}0.003796 \\
(0.040)\end{array}$ & $\begin{array}{l}0.032440 \\
(0.049)\end{array}$ \\
\hline Friday & $\begin{array}{l}0.020400 \\
(0.061)\end{array}$ & $\begin{array}{l}0.028291 \\
(0.069)\end{array}$ & $\begin{array}{l}-0.015047 \\
(0.029)\end{array}$ & $\begin{array}{l}-0.037699 \\
(0.034)\end{array}$ & $\begin{array}{l}-0.003011 \\
(0.038)\end{array}$ & $\begin{array}{l}0.004098 \\
(0.048)\end{array}$ \\
\hline Saturday & $\begin{array}{l}-0.016689 \\
(0.066)\end{array}$ & $\begin{array}{l}0.001528 \\
(0.075)\end{array}$ & $\begin{array}{l}-0.043890 \\
(0.033)\end{array}$ & $\begin{array}{l}-0.055836 \\
(0.039)\end{array}$ & $\begin{array}{l}-0.109437^{* *} \\
(0.045)\end{array}$ & $\begin{array}{l}-0.103337^{*} \\
(0.055)\end{array}$ \\
\hline Sunday & $\begin{array}{l}-0.086190 \\
(0.081)\end{array}$ & $\begin{array}{l}-0.086864 \\
(0.087)\end{array}$ & $\begin{array}{l}-0.085921^{* *} \\
(0.042)\end{array}$ & $\begin{array}{l}-0.088538^{*} \\
(0.049)\end{array}$ & $\begin{array}{l}-0.144144^{* * *} \\
(0.055)\end{array}$ & $\begin{array}{l}-0.139574^{* *} \\
(0.068)\end{array}$ \\
\hline Year Dummies & Yes & Yes & Yes & Yes & Yes & Yes \\
\hline State Dummies & Yes & Yes & Yes & Yes & Yes & Yes \\
\hline Observations & 16761 & 16761 & 65699 & 65699 & 38960 & 38960 \\
\hline Adjusted $\mathrm{R}^{2}$ & 0.302 & & 0.289 & & 0.279 & \\
\hline Pseudo $\mathrm{R}^{2}$ & & 0.089 & & 0.084 & & 0.088 \\
\hline Interaction Model: & & & & & & \\
\hline Day of the month (linear) & $\begin{array}{l}0.017337^{* *} \\
(0.008)\end{array}$ & $\begin{array}{l}0.021733^{* *} \\
(0.009)\end{array}$ & $\begin{array}{l}-0.000327 \\
(0.001)\end{array}$ & $\begin{array}{l}-0.000098 \\
(0.001)\end{array}$ & $\begin{array}{l}0.000849 \\
(0.001)\end{array}$ & $\begin{array}{l}0.001655 \\
(0.002)\end{array}$ \\
\hline Day of the month (squared) & $\begin{array}{l}-0.000506^{*} \\
(0.000)\end{array}$ & $\begin{array}{l}-0.000585^{* *} \\
(0.000)\end{array}$ & & & & \\
\hline Household Income & $\begin{array}{l}0.000176^{* * *} \\
(0.000)\end{array}$ & $\begin{array}{l}0.000207^{* * *} \\
(0.000)\end{array}$ & $\begin{array}{l}0.000173^{* * *} \\
(0.000)\end{array}$ & $\begin{array}{l}0.000213^{* * *} \\
(0.000)\end{array}$ & $\begin{array}{l}0.000123^{* * *} \\
(0.000)\end{array}$ & $\begin{array}{l}0.000182^{* * *} \\
(0.000)\end{array}$ \\
\hline $\begin{array}{l}\text { Day of the month (linear) } \\
\text { Household Income }\end{array}$ & $\begin{array}{l}0.000004^{* *} \\
(0.000)\end{array}$ & $\begin{array}{l}0.000005^{* *} \\
(0.000)\end{array}$ & $\begin{array}{l}0.000000 \\
(0.000)\end{array}$ & $\begin{array}{l}0.000001 \\
(0.000)\end{array}$ & $\begin{array}{l}-0.000001 \\
(0.000)\end{array}$ & $\begin{array}{l}-0.000001 \\
(0.000)\end{array}$ \\
\hline Year Dummies & Yes & Yes & Yes & Yes & Yes & Yes \\
\hline State Dummies & Yes & Yes & Yes & Yes & Yes & Yes \\
\hline Observations & 16761 & 16761 & 65699 & 65699 & 38960 & 38960 \\
\hline Adjusted $\mathrm{R}^{2}$ & 0.303 & & 0.289 & & 0.279 & \\
\hline Pseudo $\mathrm{R}^{2}$ & & 0.089 & & 0.084 & & 0.088 \\
\hline
\end{tabular}

Source: Own analysis, calculation and illustration, SOEP LONG Beta-Version, 2010.

Notes: Dependent variable: life satisfaction (coded: 0-10); marginal effects; robust variance estimator with clustering for persons; robust standard errors in brackets; coefficients of the models, with error probability in parentheses: ${ }^{* * *} p<0.01-{ }^{* *} p<0.05-{ }^{*} p<0.1$; cross section weights for all waves; ${ }^{a}$ household income (centered); Controlled for other exogenous variables: Health, Age, Age (squared), Child in Household, East, Household Size, Marital Status and Employment Status.

According to Table 1, men - compared to Mondays, which are used as a reference - exhibit in some cases a negative effect on life satisfaction towards the weekend, as indicated in the descriptive statistics. In men with a medium level of education, this effect is observed only on Sundays; in men with a higher level of 
education, both on Saturdays and on Sundays. Men with less education do not experience such an effect at all.

Over the course of a month, men with a low level of education exhibit a quadratically degressive influence: in other words, they experience an increase in life satisfaction, followed by a decrease, in the course of the month. Fig. 2 (c) shows that effects on life satisfaction of around 0.1 scale points can be expected in the middle of the month. The lower part of Table 1 shows for men with a low level of education a highly significant positive coefficient for the interaction variable between income and day of the month, which suggests that household income over the course of the month exerts a significant influence on the stated level of life satisfaction. Above-average household incomes produce positive effects on happiness over the course of the month, and thus have a compensatory effect on the decrease in life satisfaction towards the end of the month. Men with a medium and higher level of education are not subject to any significant happiness rhythm over the course of the month. The corresponding happiness effect for men with a low level of education may thus be subject to liquidity constraints.

Rhythms depending on the level of education have also been observed over the course of the year. Men with a low level of education experience a significant linear negative impact on life satisfaction over the course of the year, with negative effects of up to 0.25 scale points at the end of the period observed (Fig. 2e). However, it must be stressed at this point that the estimated results may be distorted due to the limited data available.

Men with a higher level of education exhibit a U-shaped pattern of life satisfaction over the course of the year. For men with a medium level of education, there are no significant seasonal effects on life satisfaction. 
Fig. 2a Weekday on Life Satisfaction:

Regression-Coefficients, Men 1994-2010

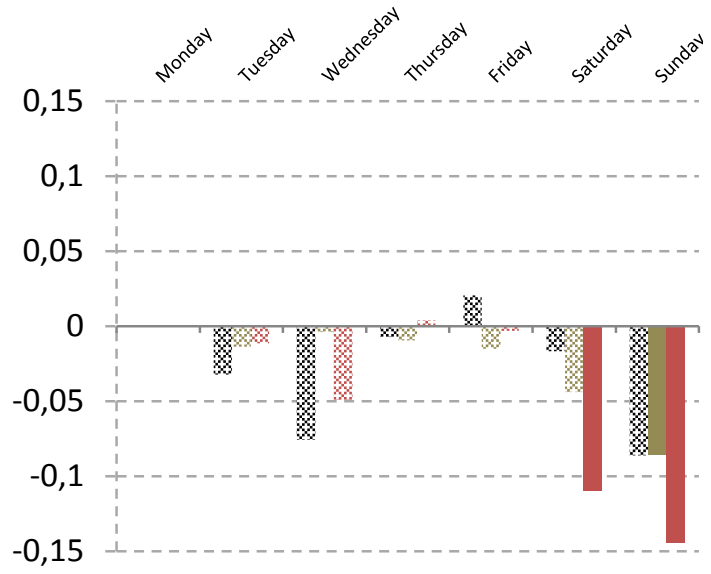

Fig. 2c Day of the month on Life Satisfaction: Estimation (regression coef.), Men $1994-2010$

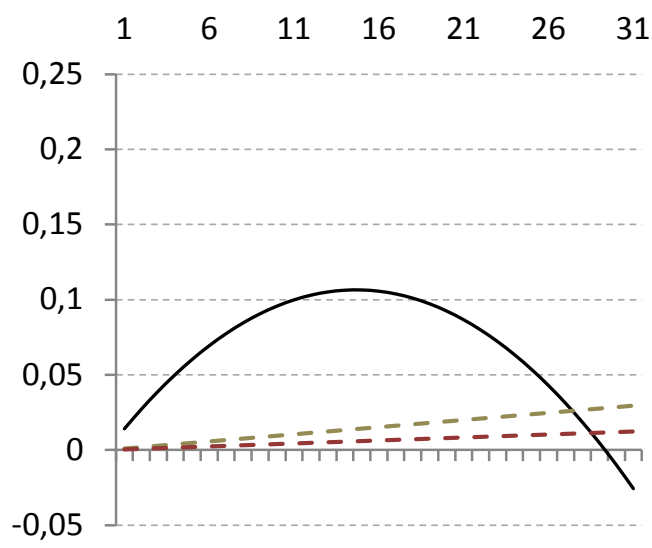

Fig. 2e Day of the year on Life Satisfaction:

Estimation (regression coef.), Men 1994- 2010

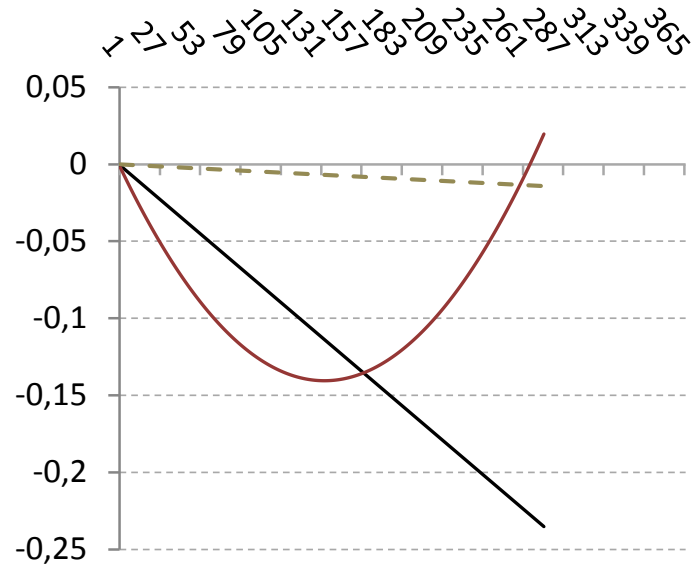

$\rightarrow$ ISCED 1, 2
Fig. $2 b$ Weekday on Life Satisfaction:

Regression-Coefficients, Women $1994-2010$

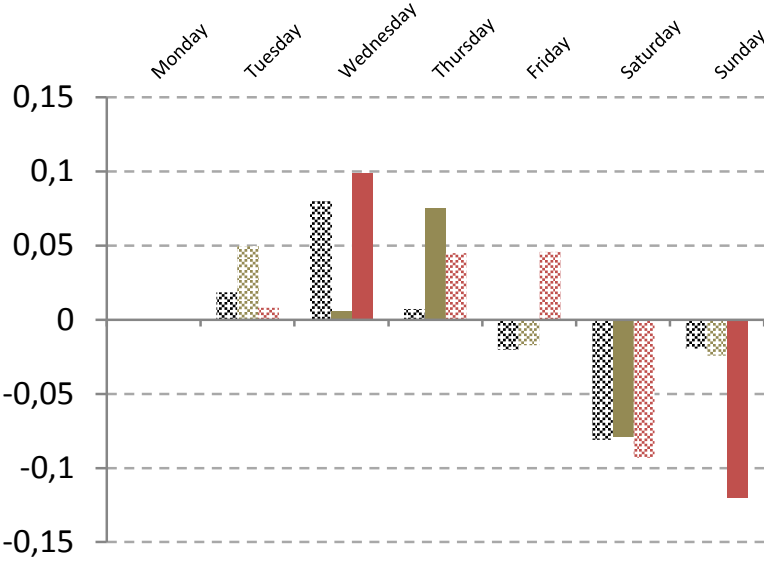

Fig. 2d Day of the month on Life Satisfaction:

Estimation (regression coef.), Women 1994 - 2010

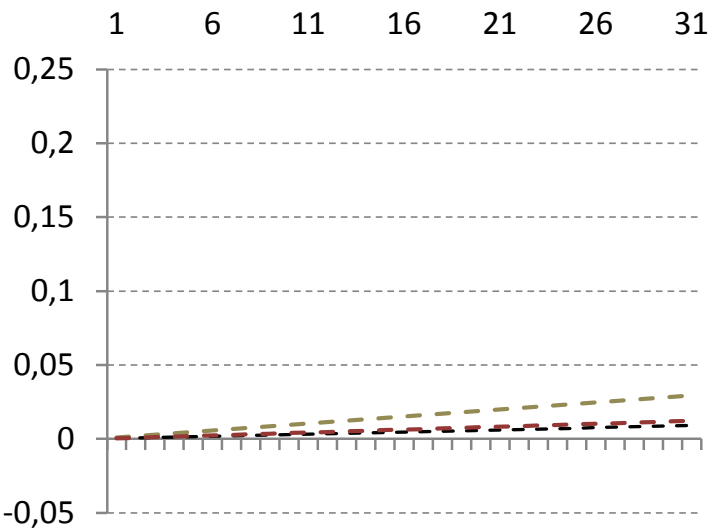

Fig. $2 f$ Day of the year on Life Satisfaction: Estimation (regression coef.), Women 1994- 2010

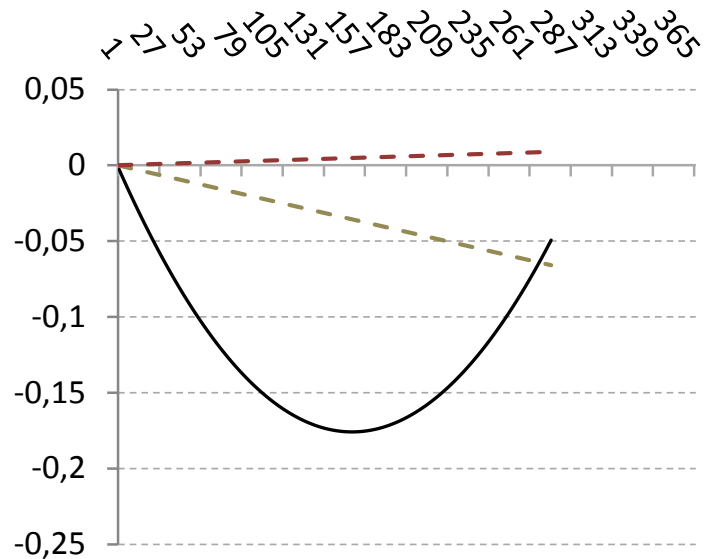

$-0,25$

-ISCED 3, 4

Source: Own analysis, calculation and illustration, SOEP LONG Beta-Version, 2010.

Notes: Life satisfaction by gender and educational level: reported beta-coefficients (solid: significance in OLS \& ologit). 
Table 2: Life Satisfaction by Day of the Week, Month and Year: Level of Education - Women (Interaction Effect between Day of the month - linear and Household Income); Cross Pool Section, 1994 - 2010, OLS and Ordered Logit Regression Results

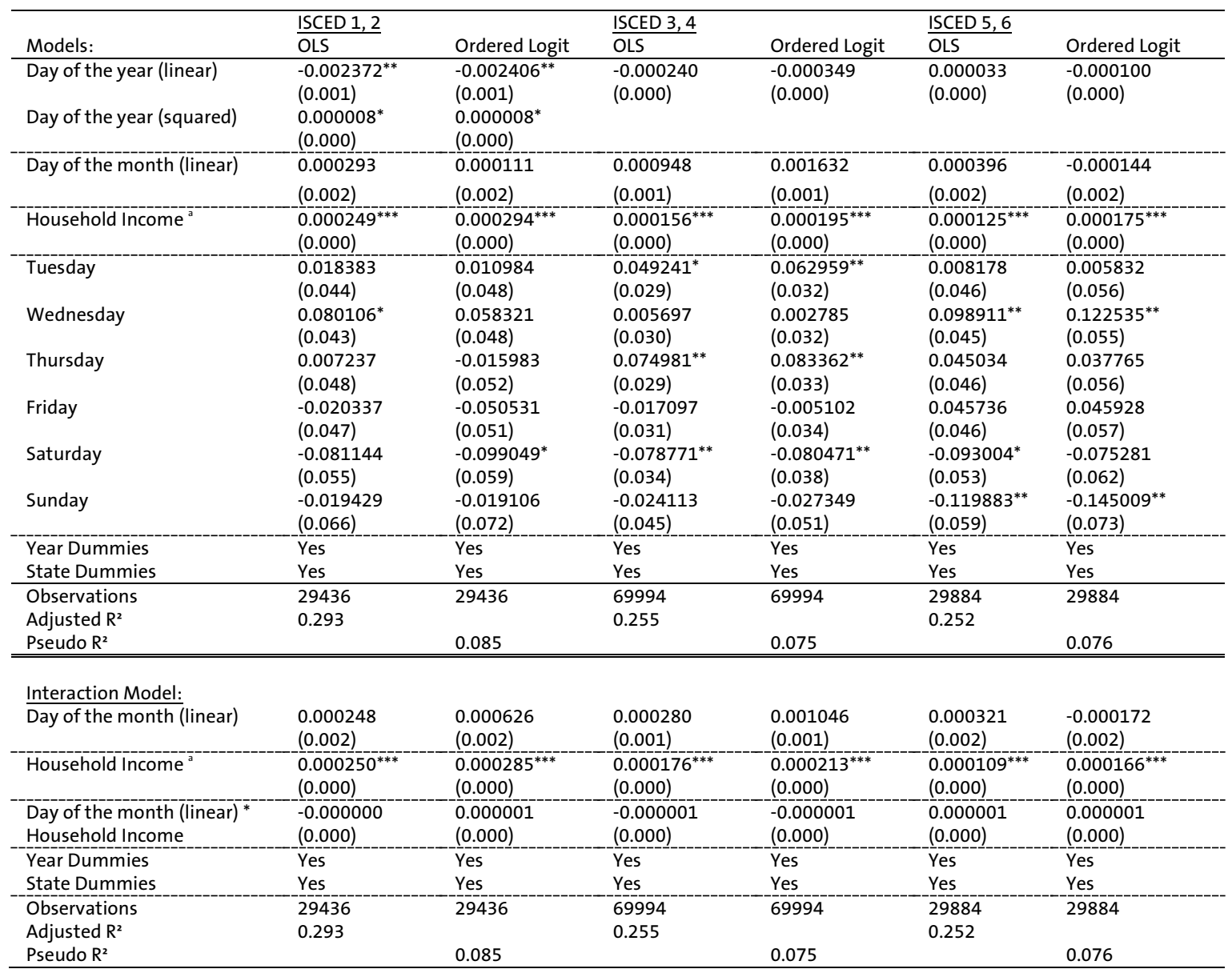

Source: Own analysis, calculation and illustration, SOEP LONG Beta-Version, 2010.

Notes: Dependent variable: life satisfaction (coded: 0-10); marginal effects; robust variance estimator with clustering for persons; robust standard errors in brackets; coefficients of the models, with error probability in parentheses: ${ }^{* * *} p<0.01$ ${ }^{* *} p<0.05-{ }^{*} p<0.1$; cross section weights for all waves; ${ }^{a}$ household income (centered); Controlled for other exogenous variables: Health, Age, Age (squared), Child in Household, East, Household Size, Marital Status and Employment Status.

Table 2 summarizes the estimated results for women; Fig. 2(b), (d) and (f) visualise the effects. First, like among men, there are education-differentiated negative weekend effects on life satisfaction. However, these are limited to Sundays for women with a higher level of education, and to Saturdays for women with a medium level of education. Over the course of the month, women of all levels of education do not exhibit any significant linear and quadratic effects? ${ }^{7}$.

${ }^{7}$ An additional check for polynomials of the third order reveals highly significant tertiary effects for women with a low level of education over the course of the month. For example, this may be interpreted as an anticipatory effect in relation to the upcoming payment of salary. Details are available from the authors upon request. 
During the year, no significant rhythms or cycles of life satisfaction have been identified for women with a medium level of education, which is the same for men with the same level of education. In the segment of low level of education, these effects are only slightly significant, but unlike for men form a U-shaped pattern. In contrast to men, there are no significant effects for women with a higher level of education.

\section{Summary and Conclusion}

We demonstrate significant cyclical and rhythmic effects of weekdays as well as of monthly and yearly patterns on life satisfaction. These effects - up to -0.14 scale points for weekdays, up to 0.21 scale points for the month and up to -0.23 scale points over the course of the year - are thus of considerable significance. Specifically, we can demonstrate that the Sunday neurosis, as reported in other studies, does not apply to the lower education segment. Moreover, it can be shown that negative effects on weekends vary by educational background and gender, which is why it is impossible to generalise about the Sunday neurosis. In terms of medium and higher education levels, it would be more appropriate to speak of a weekend neurosis.

The effects throughout the month, analysed here for the first time, reveal significant effects only for the lower education segments, which at least in the case of men are obviously driven by liquidity issues. As for life satisfaction throughout the year, there are no significant effects among men and women with a medium level of education. In segments with little or no education, men experience a decrease in life satisfaction over the course of the year; women experience such an effect only at the start of the year, but it gradually levels off from mid-April. Men of the higher education segment exhibit such a U-shaped pattern, too; women in that segment show no significant effect. The ambiguous effects over the course of the year may be attributable to a lack of sufficient data, particularly towards the end of the year. With regard to future research, it would be desirable in this context if more surveys included the entire span of a year. 


\section{Literature}

AIKEN, L. S. / WEST, S. G. (1991), Multiple Regression: Testing and Interpreting Interaction. Sage Publications, London.

AKAY, A. / MARTINSSON, P. (2009), Sundays Are Blue: Aren't They? The Day-of-the-Week Effect on Subjective Well-Being and Socio-Economic Status, IZA Discussion Paper 4563.

ARENI, C. S. / BURGER, M. (2008), Memories of "Bad" Days Are More Biased Than Memories of "Good" Days: Past Saturdays Vary, but Past Mondays Are Always Blue. Journal of Applied Social Psychology 38, 1395-1415.

BOERTIEN, D., / VON SCHEVE, C. / PARK, M. (2012), Education, personality and separation: The distribution of relationship skills across society. SOEPpapers 487.

CLARK, A. E. / OSWALD, A. J. (1994), Unhappiness and Unemployment. Economic Journal 104, 648-659.

CLARK, L. A. / WATSON, D. (1988), Mood and the mundane: Relations between daily life events and self-reported mood. Journal of Personality and Social Psychology 54, 296308.

CROFT, G. P. / WALKER, A. E. (2001), Are Monday blues all in the mind? The role of expectancy in the subjective experience of mood. Journal of Applied Social Psychology 31, 1133-1145.

CSIKSZENTMIHALYI, M. / HUNTER, J. (2003), Happiness in everyday life: The uses of experience sampling. Journal of Happiness Studies 4, 185-199.

DIENER, E. / SUH, E. M. / LUCAS, R. E. / SMITH, H. L. (1999), Subjective well-being: three decades of progress. Psychological Bulletin 125, 276-302.

EASTERLIN, R. A. (1995), Will Raising the Incomes of All Increase the Happiness of All? Journal of Economic Behavior \& Organization 27, 35-47.

FERRER-I-CARBONELL, A. / FRIJTERS, P. (2004), How important is methodology for the estimates of the determinants of happiness? Economic Journal 114, 641-659.

FRIJTERS, P. / BEATTON, T. (2012), The mystery of the U-shaped relationship between happiness and age. Journal of Economic Behavior \& Organization 82, 525-542.

LUCAS, R. E. / DIENER, E. / SUH, E. M. (1996), Discriminant Validity of Well-Being Measures. Journal of Personality and Social Psychology 71, 616-628.

MAENNIG, W. / WILHELM, M. (2012), Becoming (un)employed and life satisfaction: asymmetric effects and potential omitted variable bias in empirical happiness studies. Applied Economics Letters 19, 1719-1722.

MIHALCEA, R. / LIU, H. (2006), A corpus-based approach to finding happiness, in Computational Approaches to Analyzing Weblogs: Papers from the 2006 Spring Symposium, (Eds) N. Nicolov, F. Salvetti, M. Liberman and J. H. Martin, AAAI Press, Menlo Park (CA.), pp. 139-144.

MUFFELS, R. / HEADY, B. (2013), Capabilities and Choices: Do They Make Sen'se for Understanding Objective and Subjective Well-Being? Social Indicators Research 110, 1159-1185.

MURRAY, G., / ALLEN, N. B. / TRINDER, J. (2001), A longitudinal investigation of seasonal variation in mood. Chronobiology International 18, 875-891. 
SMITH, T. W. (1979), Happiness: Time Trends, Seasonal Variations, Intersurvey Differences, and Other Mysteries. Social Psychology Quarterly 42, 18-30.

STUTZER, A. / FREY, B. S. (2010), Recent advances in the economics of individual subjective well-being. Social Research 77, 679-714.

TAYLOR, M. P. (2006), Tell me why I don't like Mondays: Investigating day of the week effects on job satisfaction and psychological well-being. Journal of the Royal Statistical Society Series A 169, 127-142.

WINKELMANN, L. / WINKELMANN, R. (1998), Why are the unemployed so unhappy? Evidence from panel data. Economica 65, 1-15. 


\section{Hamburg Contemporary Economic Discussions}

(Download: http://www.uni-hamburg.de/economicpolicy/hced.html)

46

45

44

MAENNIG, W. / STEENBECK, M. / WILHELM, M.: Rhythms and Cycles in Happiness, 2013.

RICHTER, F. / STEENBECK, M. / WILHELM, M.: The Fukushima Accident and Policy Implications: Notes on Public Perception in Germany, 2014 (2 $2^{\text {nd }}$ version).

MAENNIG, W.: London 2012 - das Ende des Mythos vom erfolgreichen Sportsoldaten, 2012.

MAENNIG, W. / WELLBROCK, C.: London 2012 - Medal Projection Medaillenvorausberechnung, 2012.

MAENNIG, W. / RICHTER, F.: Exports and Olympic Games: Is there a Signal Effect? 2012.

MAENNIG, W. / WILHELM, M.: Becoming (Un)employed and Life Satisfaction: Asymmetric Effects and Potential Omitted Variable Bias in Empirical Happiness Studies, 2011.

MAENNIG, W.: Monument Protection and Zoning in Germany: Regulations and Public Support from an International Perspective, 2011.

BRANDT, S. / MAENNIG, W.: Perceived Externalities of Cell Phone Base Stations - The Case of Property Prices in Hamburg, Germany, 2011.

MAENNIG, W. / STOBERNACK, M.: Do Men Slow Down Faster than Women? 2010.

DU PLESSIS, S. A. / MAENNIG, W.: The 2010 World Cup High-frequency Data Economics: Effects on International Awareness and (Self-defeating) Tourism, 2010.

BISCHOFF, O.: Explaining Regional Variation in Equilibrium Real Estate Prices and Income, 2010.

FEDDERSEN, A. / MAENNIG, W.: Mega-Events and Sectoral Employment: The Case of the 1996 Olympic Games, 2010.

FISCHER, J.A.V. / SOUSA-POZA, A.: The Impact of Institutions on Firms Rejuvenation Policies: Early Retirement with Severance Pay versus Simple Lay-Off. A Cross-European Analysis, 2010.

FEDDERSEN, A. / MAENNIG, W.: Sectoral Labor Market Effects of the 2006 FIFA World Cup, 2010. 


\section{Hamburg Contemporary Economic Discussions}

(Download: http://www.uni-hamburg.de/economicpolicy/hced.html)

AHLFELDT, G.: Blessing or Curse? Appreciation, Amenities, and Resistance around the Berlin "Mediaspree", 2010.

FALCH, T. / FISCHER, J.A.V.: Public Sector Decentralization and School Performance: International Evidence, 2010.

AHLFELDT, G. / MAENNIG, W. /ÖLSCHLÄGER, M.: Lifestyles and Preferences for (Public) Goods: Professional Football in Munich, 2009.

FEDDERSEN, A. / JACOBSEN, S. / MAENNIG, W.: Sports Heroes and Mass Sports Participation - The (Double) Paradox of the "German Tennis Boom", 2009.

AHLFELDT, G. / MAENNIG, W. / OSTERHEIDER, T.: Regional and Sectoral Effects of a Common Monetary Policy: Evidence from Euro Referenda in Denmark and Sweden, 2009.

BJØRNSKOV, C. /DREHER, A. /FISCHER, J.A.V. /SCHNELLENBACH, J.: On the Relation Between Income Inequality and Happiness: Do Fairness Perceptions Matter? 2009.

AHLFELDT, G. / MAENNIG, W.: Impact of Non-Smoking Ordinances on Hospitality Revenues: The Case of Germany, 2009.

FEDDERSEN, A. / MAENNIG, W.: Wage and Employment Effects of the Olympic Games in Atlanta 1996 Reconsidered, 2009.

AHLFELDT, G. / FRANKE, B. / MAENNIG, W.: Terrorism and the Regional and Religious Risk Perception of Foreigners: The Case of German Tourists, 2009.

AHLFELDT, G. / WENDLAND, N.: Fifty Years of Urban Accessibility: The Impact of Urban Railway Network on the Land Gradient in Industrializing Berlin, 2008.

AHLFELDT, G. / FEDDERSEN, A.: Determinants of Spatial Weights in Spatial Wage Equations: A Sensitivity Analysis, 2008.

MAENNIG, W. /ALLMERS, S.: South Africa 2010: Economic Scope and Limits, 2008.

MAENNIG, W. / WELLBROCK, C.-M.: Sozio-ökonomische Schätzungen Olympischer Medaillengewinne: Analyse-, Prognose- und Benchmarkmöglichkeiten, 2008. 


\section{Hamburg Contemporary Economic Discussions}

(Download: http://www.uni-hamburg.de/economicpolicy/hced.html)

19

18

AHLFELDT, G.: The Train has Left the Station: Real Estate Price Effects of Mainline Realignment in Berlin, 2008.

MAENNIG, W. / PORSCHE, M.: The Feel-good Effect at Mega Sport Events - Recommendations for Public and Private Administration Informed by the Experience of the FIFA World Cup 2006, 2008.

AHLFELDT, G. / MAENNIG, W.: Monumental Protection: Internal and External Price Effects, 2008.

FEDDERSEN, A. / GRÖTZINGER, A. / MAENNIG, W.: New Stadia and Regional Economic Development - Evidence from FIFA World Cup 2006 Stadia, 2008.

AHLFELDT, G. / FEDDERSEN, A.: Geography of a Sports Metropolis, 2007.

FEDDERSEN, A. / MAENNIG, W.: Arenas vs. Multifunctional Stadia - Which Do Spectators Prefer? 2007.

AHLFELDT, G.: A New Central Station for a Unified City: Predicting Impact on Property Prices for Urban Railway Network Extension, 2007.

AHLFELDT, G.: If Alonso was Right: Accessibility as Determinant for Attractiveness of Urban Location, 2007.

AHLFELDT, G., MAENNIG, W.: Assessing External Effects of City Airports: Land Values in Berlin, 2007.

MAENNIG, W.: One Year Later: A Re-Appraisal of the Economics of the 2006 Soccer World Cup, 2007.

HAGN, F. / MAENNIG, W.: Employment Effects of the World Cup 1974 in Germany.

HAGN, F. / MAENNIG W.: Labour Market Effects of the 2006 Soccer World Cup in Germany, 2007.

JASMAND, S. / MAENNIG, W.: Regional Income and Employment Effects of the 1972 Munich Olympic Summer Games, 2007.

DUST, L. / MAENNIG, W.: Shrinking and Growing Metropolitan Areas Asymmetric Real Estate Price Reactions? The Case of German Singlefamily Houses, 2007.

HEYNE, M. / MAENNIG, W. / SUESSMUTH, B.: Mega-sporting Events as Experience Goods, 2007. 


\section{Hamburg Contemporary Economic Discussions}

(Download: http://www.uni-hamburg.de/economicpolicy/hced.html)

04

03

02

01

$04 / 2006$

$03 / 2006$

$02 / 2006$

$01 / 2006$

$04 / 2005$

$03 / 2005$

$02 / 2005$

$01 / 2005$
DU PLESSIS, S. / MAENNIG, W.: World Cup 2010: South African Economic Perspectives and Policy Challenges Informed by the Experience of Germany 2006, 2007.

AHLFELDT, G. / MAENNIG, W.: The Impact of Sports Arenas on Land Values: Evidence from Berlin, 2007.

FEDDERSEN, A. / MAENNIG, W. / ZIMMERMANN, P.: How to Win the Olympic Games - The Empirics of Key Success Factors of Olympic Bids, 2007.

AHLFELDT, G. / MAENNIG, W.: The Role of Architecture on Urban Revitalization: The Case of "Olympic Arenas" in Berlin-Prenzlauer Berg, 2007.

MAENNIG, W. / SCHWARTHOFF, F.: Stadium Architecture and Regional Economic Development: International Experience and the Plans of Durban, October 2006.

FEDDERSEN, A. / VÖPEL, H.: Staatliche Hilfen für Profifußballclubs in finanziellen Notlagen? - Die Kommunen im Konflikt zwischen Imageeffekten und Moral-Hazard-Problemen, September 2006.

FEDDERSEN, A.: Measuring Between-season Competitive Balance with Markov Chains, July 2006.

FEDDERSEN, A.: Economic Consequences of the UEFA Champions League for National Championships - The Case of Germany, May 2006.

BUETTNER, N. / MAENNIG, W. / MENSSEN, M.: Zur Ableitung einfacher Multiplikatoren für die Planung von Infrastrukturkosten anhand der Aufwendungen für Sportstätten - eine Untersuchung anhand der FußballWM 2006, May 2005.

SIEVERS, T.: A Vector-based Approach to Modeling Knowledge in Economics, February 2005.

SIEVERS, T.: Information-driven Clustering - An Alternative to the Knowledge Spillover Story, February 2005.

FEDDERSEN, A. / MAENNIG, W.: Trends in Competitive Balance: Is there Evidence for Growing Imbalance in Professional Sport Leagues? January 2005. 


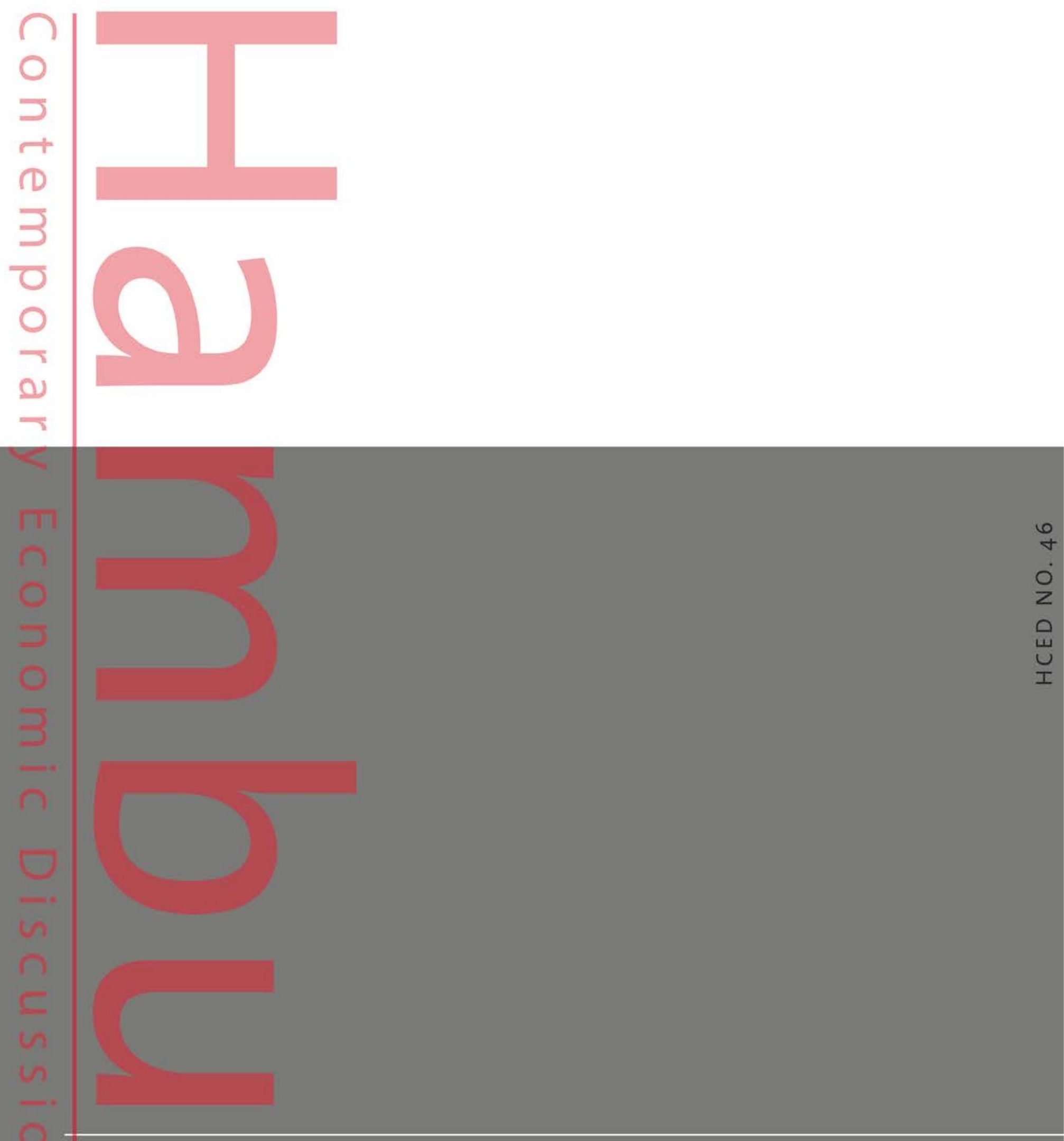

ISSN 1865-2441 (PRINT)

ISSN 1865-7133 (ONLINE)

ISBN 978-3-942820-06-6 (PRINT) ISBN 978-3-942820-07-3 (ONLINE) 